\title{
Deltamethrin toxicological profile of peridomestic Triatoma sordida in the North of Minas Gerais, Brazil
}

\author{
Grasielle Caldas DÁvila Pessoa ${ }^{*}$, Marcos Takashi Obara², João G Rezende ${ }^{3}$, Bernardino Vaz de Mello \\ Marcela Lencine Ferraz ${ }^{4}$ and Liléia Diotaiuti ${ }^{1}$
}

\begin{abstract}
Background: In general, there was a large reduction in the occurrence of cases of Chagas disease in the last decades in Brazil. However, despite all of these efforts, there have been various reports of persistent reinfestations of T. sordida in a large part of the state of Minas Gerais, for reasons still little investigated. Thus, this purpose of this study was to characterize the deltamethrin susceptibility profile of peridomestic T. sordida populations from North of Minas Gerais - Brazil.

Methods: Susceptibility to deltamethrin was assessed in seventeen peridomestic populations of T. sordida from North region of Minas Gerais, Brazil. Serial dilutions of deltamethrin in acetone $(0.2 \mu \mathrm{L})$ were topically applied in first instar nymphs (F1, five days old, fasting, weight $1.2 \pm 0.2 \mathrm{mg}$ ). Dose response results were analyzed with POLO program, determining the lethal doses, slope and resistance ratios (RR).

Results: Susceptibility profile characterization of $T$. sordida populations revealed resistance ratios $\left(R R_{50}\right)$ ranging from 2.50 to 7.08 .

Conclusions: In fact, we know very little about the real impact of the resistance ratios obtained in the laboratory bioassays on the effectiveness of the vector control activities in the field. Thus, we prefer to refer to the populations with RR $>5$ as populations with altered susceptibility. For these populations, the realization of laboratory and field trials, simultaneous and complementary, permitting the evaluation of both, is recommended.
\end{abstract}

Keywords: Triatominae, Triatoma sordida, Minas Gerais, Insecticide resistance, Deltamethrin

\section{Background}

Chagas disease $(\mathrm{CD})$, or American trypanosomiasis, is a public health concern in most Latin American countries. About 7 million people are infected by causative agent of this disease, Trypanosoma cruzi (Kinetoplastida; Trypanosomatidae) [1]. In Brazil, it has been estimated that approximately 1.8 to 2.5 million people are currently infected [2]. Considering the absence of a vaccine and the limited efficacy of the currently available parasiticide drugs, the main approaches to control are based on insecticidal control of insect vectors.

\footnotetext{
* Correspondence: grasielle@cpqrr.fiocruz.br

'Laboratório de Triatomíneos e Epidemiologia da Doença de Chagas/CPqRR/ FIOCRUZ, Centro de Pesquisas René Rachou, Fundação Oswaldo Cruz, Av. Augusto de Lima 1715, Barro Preto, 29190-002 Belo Horizonte, MG, Brazil Full list of author information is available at the end of the article
}

With the priorisation of the areas of Triatoma infestans, the prevalence of $\mathrm{CD}$ was reduced from approximately 18 million to the current 9 million, in little more than 15 years [2]. A marked reduction in the distribution of domestic vector transmission of the disease, by $\mathrm{T}$. infestans, was also achieved, resulting in the interruption of the vector transmission of the disease by $T$. infestans in Brazil [3]. The recolonization of the areas originally occupied by Triatoma infestans, by secondary species, became a reality, bringing out the Triatoma sordida. $T$. sordida is currently considered as a possible substitute to the present domestic vector $T$. infestans in the transmission of T. cruzi. The process of domiciliation for $T$. sordida may be associated with a previous eradication of T.infestans, considering the better ability to obtain blood meals in the latter species, associated at the rarity of mixed populations where these two species occur in 
simpatry [4]. In Central Brazil, T. sordida is a triatomine that represents the greatest risk for the transmission of Chagas Disease [5].

T. sordida is a tritomine endemic in the savanna areas, living mainly under the bark of trees that remain preserved in the process of forming fields and pastures. Some biological characteristics of this triatomine, such as its resistance capacity to fasting, its ease in adapting to different hosts and relative mobility (mainly of the adults) facilitates its process of dispersion and colonization of artificial ecotopes [6-12]. The frequency with which $T$. sordida has been found in peridomicile and intradomicile environments, has characterized it as a semidomestic species [13]. In spite of the spraying difficulties and the low permanence of the pyrethroid insecticide in peridomiciliar environments, the existence of just one annual triatomine cycle and the slowness of original population reconstruction suggest that one annual spraying is sufficient for the control of this triatomine [14].

In general, there was a large reduction in the occurrence of cases of $\mathrm{CD}$ in the last decades in Brazil. This was possibly due to epidemiological vigilance, linked to the chemical control activities of the Chagas Disease Control Program as well as the improvement of socioeconomic factors in the rural areas - income improvement, habitation improvements, electricity, access to health and education [15]. However, despite all of these efforts, there have been various reports of persistent reinfestations of $T$. sordida in a large part of the state of Minas Gerais, for reasons still little investigated.

In this context, studies investigating a possible insecticide resistance in Brazilian T. sordida has been made. The susceptibility of 11 populations of T. sordida, collected in the states of Goiás, (GO), Mato Grosso (MT), and Mato Grosso do Sul (MS) to deltamethrin, revealed high levels of susceptibility $\left(\mathrm{RR}_{50} 1.19\right.$ to 2.26$)$ [16]. The evaluation of susceptibility to deltamethrin of 103 populations of $T$. sordida collected in the Triângulo, Central and Northern part of the state of Minas Gerais, showed just one resistant population $\left(\mathrm{RR}_{50}\right.$ 6.5) [17]. Thus, the objective of this present work was to characterize the deltamethrin toxicological profile of peridomestic T.sordida in the Northern region of Minas Gerais, originating from the areas with persistent reinfestations.

\section{Methods}

\section{Insect sampling}

The study was carried out in the Northern region of Minas Gerais (Brazil), area which presents the largest index of poverty in the State. Similar in many aspects to the Brazilian Northeast, this region shows extensive areas of transition between the savanna and the caatinga. In the 1980s, the cotton culture expanded representing nearly all of the agricultural investment in the region.
The only reason deforestation did not reach the entire area was because of the cotton culture failure resulting from the introduction of pests and lack of financial support. This stimulated the migration of the rural population from areas with a high prevalence of Chagas disease $(\mathrm{CD})$, to urban centers. For the subsisting rural population remained the possibility of using residual forests for the production of charcoal, or land sale and of physical labor for the reforestation with eucalyptus (growing in recent years in the area) [18].

The study triatomines populations were manually collected, without using a dislodging agent, in the peridomiciles in endemic areas of the North of Minas Gerais (Monte Azul - 16 $6^{\circ} 13^{\prime} 01^{\prime \prime} \mathrm{S} 44^{\circ} 54^{\prime} 21^{\prime \prime} \mathrm{O}$, Monjolos $20^{\circ} 1^{\prime} 29^{\prime \prime} \mathrm{S}, 48^{\circ} 56^{\prime} 27^{\prime \prime} \mathrm{W}$, Buenópolis - $17^{\circ} 52^{\prime} 22^{\prime \prime}$ $\mathrm{S}, 44^{\circ} 10^{\prime} 48^{\prime \prime} \mathrm{W}$, Presidente Juscelino - $18^{\circ} 38^{\prime} 13^{\prime \prime} \mathrm{S}$ $44^{\circ} 03^{\prime} 28^{\prime \prime} \mathrm{O}$, Coração de Jesus $16^{\circ} 41^{\prime} 06^{\prime \prime} \mathrm{S} 44^{\circ} 21^{\prime}$ 54" O, Bocaiuva $17^{\circ} 06^{\prime} 28^{\prime \prime} \mathrm{S} 43^{\circ} 48^{\prime} 54^{\prime \prime} \mathrm{O}$ ), in which the Chagas Disease Control Program were performed systematic applications of insecticides with residual action in the last 29 years (Figure 1).

\section{Chemicals}

Technical grade Deltamethrin (99.1\%) used for bioassay was obtained from Bayer CropScience, Brazil. The analytical grade acetone used for dilutions was purchased from Merck, Germany.

\section{Dose-response bioassays}

The susceptibility reference lineage (SRL) of T. sordida came from Uberaba (19 44' $52^{\prime \prime} \mathrm{S} 47^{\circ} 55^{\prime} 55^{\prime \prime} \mathrm{O}$ ), preserved in the laboratory for more than 20 years, without contact with insecticide and inclusion of external material was used [19].

Serial dilutions of deltamethrin in acetone were prepared. For each concentration, three repetitions were carried out with ten first instar nymphs of $\mathrm{F} 1$ generation (five days old, fasting, weight of $1.2 \pm 0.2 \mathrm{mg}$ ). The treatment consisted of the application of $0.2 \mu \mathrm{L}$ of insecticide dilution on the dorsal abdomen, according to the World Health Organization [20] and Pessoa [21] procedures, with the aid of a Hamilton mycro-syringe mounted on a repeating dispenser. For each population, a minimum of eight doses of insecticide active ingredient (a.i.) ranging from 0.01 to $4.0 \mathrm{ng}$ and killing between $>0 \%$ to $<100 \%$ of the individuals, were applied per insect. Acetone was applied to the control group. The mortality was assessed 72 hours after application and it was determined by the inability or lack of coordination of the nymphs to move from the center to the edge of the filter paper $(7 \mathrm{~cm}$ diameter). Signs of paralysis and lack of response to external stimuli was considered as well. During and after the experiment, the insects were kept under controlled conditions of temperature and humidity $\left(25^{\circ} \mathrm{C} \pm 1^{\circ} \mathrm{C}\right.$; 


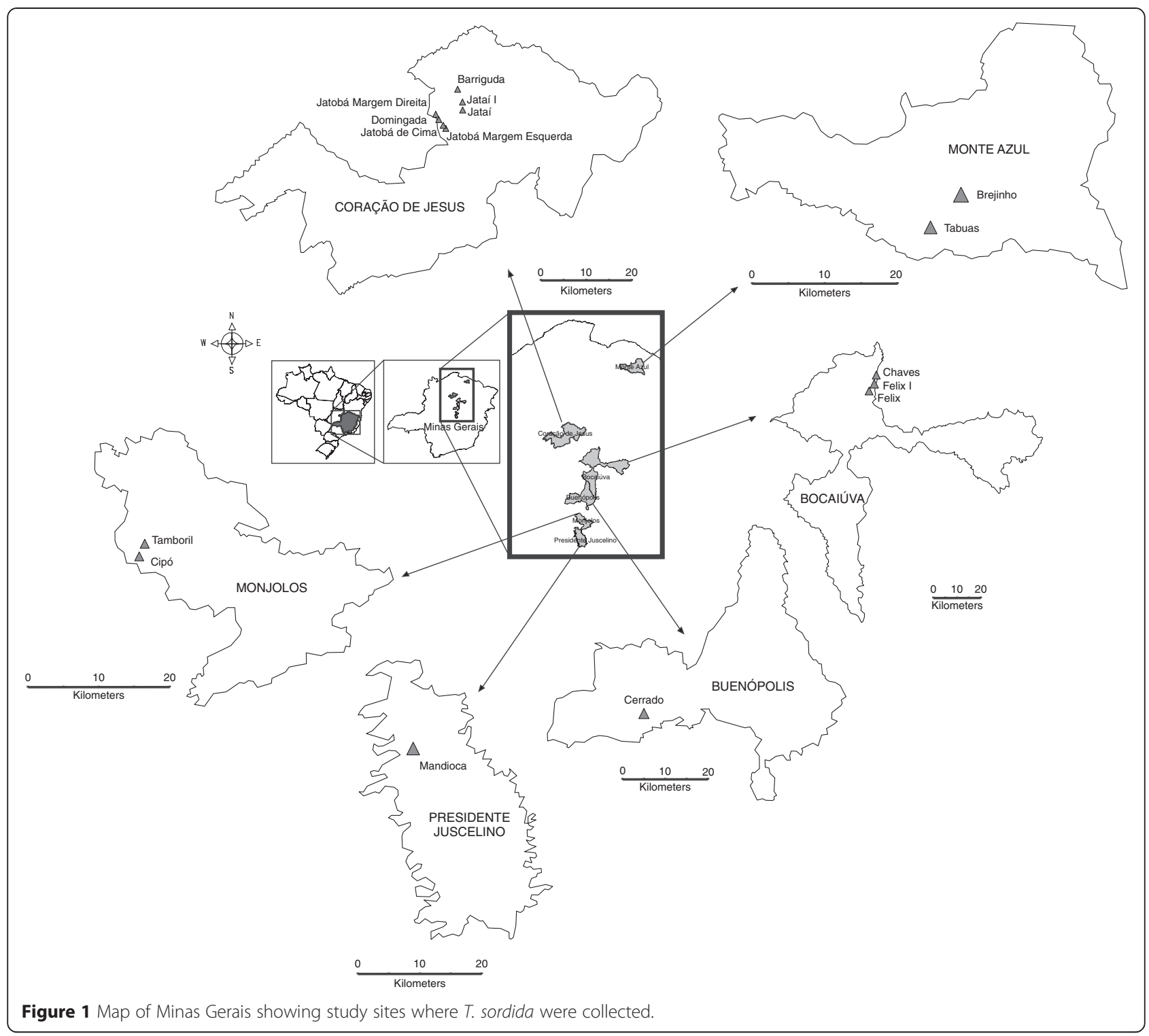

$60 \% \pm 10 \% \mathrm{RH})$. Probit analysis [22] was performed on mortality data using POLO program [23] to determine the $\mathrm{LD}_{50}$. Dosages were expressed as nanograms of active ingredient (ng. i.a.) per treated nymph. The Resistance Ratio $\left(R_{50}\right)$ was calculated as the quotient of $L_{50}$ value for field population divided by the $\mathrm{LD}_{50}$ value obtained for the SRL.

This study was approved by the Animal Ethics Committee of Fundação Oswaldo Cruz (n’. 29/14-1).

\section{Results}

The susceptibility reference lineage presented an $\mathrm{LD}_{50}$ of $0.064 \mathrm{ng}$ a.i./nymph treated. The susceptibility profile characterization of $T$. sordida populations revealed $R_{50}$ values ranging from 2.6 to 6.8. All population presented slope equal or higher than the slope of the SRL, revealing equal or lower heterogeneity in the toxicological response including individuals that resist higher doses of insecticides (Table 1).

\section{Discussion}

Despite Triatoma sordida being the most captured species in Central Brazil and that this species is associated with ever increasing frequent reports of persistent reinfestations, making vector control more difficult, there are still few studies that investigate the resistance of these vectors to insecticides.

In this work, the characterization of deltamethrin susceptibility profile in 14 populations of $T$. sordida collected in areas of persistent reinfestation in Northern Minas Gerais, revealed the biggest resistance ratios already identified for populations of T. sordida $\left(R_{50} 2.5\right.$ 
Table 1 Toxicological profile to deltamethrin in peridomestic Triatoma sordida from North of Minas Gerais, Brazil

\begin{tabular}{|c|c|c|c|c|}
\hline $\begin{array}{l}\text { Population: } \\
\text { municipality }\end{array}$ & Location & $\begin{array}{c}\text { LD }_{50}(95 \% \mathrm{Cl}) \\
\text { (ng i.a. / nymph) }\end{array}$ & $\begin{array}{c}\mathbf{R R}_{50} \\
(95 \% \mathrm{Cl})\end{array}$ & Slope \pm SD \\
\hline Uberaba - SRL & - & $0.066(0.055-0.077)$ & $1.00(5.74-8.74)$ & $5.315 \pm 0.664$ \\
\hline Monjolos & Cipó & $0.165(0.114-0.234)$ & $2.50(1.97-3.17)$ & $4.878 \pm 0.664$ \\
\hline Coração de Jesus & Jataí & $0.180(0.131-0.234)$ & $2.73(2.14-3.50)$ & $4.804 \pm 0.727$ \\
\hline Buenópolis & Cercado & $0.223(0.134-0.314)$ & $3.39(2.71-4.24)$ & $5.954 \pm 1.011$ \\
\hline Monte Azul & Tábuas & $0.228(0.207-0.249)$ & $3.47(2.89-4.17)$ & $9.975 \pm 1.490$ \\
\hline Coração de Jesus & Jatobá de Cima & $0.235(0.185-0.286)$ & $3.58(2.74-4.66)$ & $4.578 \pm 0.656$ \\
\hline Monte Azul & Brejinho & $0.236(0.129-0.333)$ & $3.59(2.69-4.80)$ & $4.763 \pm 0.755$ \\
\hline Coração de Jesus & Jatobá & $0.269(0.196-0.335)$ & $4.08(3.94-4.74)$ & $4.834 \pm 1.002$ \\
\hline Monjolos & Tamboril & $0.285(0.248-0.329)$ & $4.34(3.51-5.36)$ & $5.864 \pm 0.822$ \\
\hline Bocaiúva & Félix & $0.288(0.240-0.335)$ & $4.38(3.49-5.50)$ & $5.784 \pm 0.873$ \\
\hline Coração de Jesus & Domingada & $0.331(0.252-0.436)$ & $5.03(4.08-6.21)$ & $6.388 \pm 0.945$ \\
\hline Presidente Juscelino & Mandioca & $0.354(0.263-0.453)$ & $5.39(4.28-6.78)$ & $5.629 \pm 0.790$ \\
\hline Bocaiúva & Chaves & $0.372(0.326-0.434)$ & $5.66(4.57-7.00)$ & $7.552 \pm 0.999$ \\
\hline Bocaiúva & Félix I & $0.399(0.289-0.515)$ & $6.06(4.82-7.63)$ & $5.791 \pm 0.918$ \\
\hline Coração de Jesus & Barriguda & $0.465(0.404-0.535)$ & $7.08(5.74-8.74)$ & $6.834 \pm 1.033$ \\
\hline
\end{tabular}

SRL: susceptibility reference lineage; $\mathbf{L D}_{\mathbf{5 0}} \mathbf{5 0 \%}$ lethal dose; $\mathbf{9 5} \% \mathbf{C l}$ : $95 \%$ confidence interval; $\mathbf{n g}$ i.a: nanograms of active ingredient; $\mathbf{R R}_{\mathbf{5 0}} \mathbf{5 0} \%$ resistance ratio; SD: standard deviation.

to 7.2). The current knowledge of pyrethroids toxicological profile in Brazilian triatomines is limited. Studies have been done with $T$. infestans [24,25], Triatoma brasiliensis [16], Panstrongylus megistus [26] and T. sordida $[21,27,28]$ showing reduced resistance ratios values $\left(R_{50}\right.$ 0.7 to 7.0) when compared with triatomines from Bolivia $\left(\mathrm{RR}_{50} 0.62\right.$ to 818.0$)$ [25,29-37] and Argentina $\left(\mathrm{RR}_{50} 0.9\right.$ to 1419.6) [24,29-31,35,36,38-43]. According to OPAS [19], for populations with $R R<5$, the alteration of susceptibility observed is related to individual variations, and the maintenance of control activities with the utilized insecticide and continuity with the monitoring activities is recommended. However, the populations with $\mathrm{RR}_{50}>5$ are considered resistant - Coração de Jesus/Domingada $\left(R_{50}\right.$ 5.0), Presidente Juscelino/Mandioca $\left(R_{50} 5.3\right)$, Bocaiúva/Chaves $\left(\mathrm{RR}_{50} 5.6\right)$, Bocaiúva/Felix $\mathrm{I}\left(\mathrm{RR}_{50} 6.0\right)$ and Coração de Jesus/Barriguda $\left(R_{50} 7.2\right)$. In this case is recommended: 1) to investigate the operational failures in the strategies control vector realized by Chagas Disease Control Program - CDCP; 2) to change the insecticide used for CDCP by other, with distinct mode of action, 3) to continue the susceptibility monitoring studies on the timeline.

In fact, we know very little about the real impact of the resistance ratios obtained in the laboratory bioassays on the effectiveness of the vector control activities in the field. Thus, we prefer to refer to the populations with RR $>5$ as populations with altered susceptibility. For these populations, the realization of laboratory and field trials, simultaneous and complementary, permitting the evaluation of both, is recommended. These trials will permit establishment beyond conceptual cut-off points for phenotype resistance, define operational cut-off points that permit the adoption of intervention measures in opportune moments by reverting the resistance frame, not detrimental to the few available insecticides for triatomine density control. It is highlighted here that the continued pressure with insecticide demands that evaluations of this type be made on a continuous timeline, since the population profiles can be altered.

The different deltamethrin susceptibility profile observed in populations of distinct locations, nevertheless belonging to the same municipalities (ex. Coração de Jesus/Jataí $\mathrm{RR}_{50} 2.7$ and Coração de Jesus/Barriguda $\mathrm{RR}_{50}$ 7.2), reinforce the complexity of the resistance phenotype, not only at the macrogeographical level, but at the microgeographical level. Different toxicity of deltamethrin was detected between dwellings of Chaco province, accounting for both susceptible and resistant houses within the same locality in T. infetans populations [44]. Deltatmethrin appears not to present homogenous effects over different populations, suggesting independent selection processes facing pressure with the insecticide.

Slope values have been used as indicators of population heterogeneity. High slope values are related to low genetic variation, whereas populations in process of selection and thus showing genetic variation relate to less step slopes (when compared to SRL slope) [45]. Of the 14 studied populations, all populations presented equal or higher slope to that of the LRS, suggesting the lack or reduced possibility of deltamethrin toxicological profile change on the timeline should be considered, when submitted to the continuous pressure with insecticide. 
With the decentralization of the Chagas Disease Control Program in 1999 [46] a growth in demobilization of the vector control activities for $\mathrm{CD}$ were observed. The inexistence of career plans and the low salaries of health agents have reflected in a large rotation of these professionals, which without supervision on the field have developed their activities with questionable quality. In addition to this, with the Certification of the Interruption of Chagas disease by Triatoma infestans in Brazil in 2006 [3] a reduction in the priority of the control actions of $\mathrm{CD}$ was confirmed, connected to the loss of recognizing the importance of the disease faced with the emergencies of other endemics. This situation may directly reflect on the sustainability of the control levels reached, fruits of decades of effort by agents and health managers.

In this context, the alteration of the susceptibility observed in this work's study populations may be related to operational failures, caused by: 1) the lack of insecticide efficiency related to the poor quality of active ingredients and/or inadequate formulation; 2) operational failures related to the lack of training of endemic agents [17], 3) environmental conditions, mainly in peridomicile, responsible for the more accelerated degradation of the insecticide $[47-49]$; 4) complexity of peridomiciles of the region tied to the behavioral characteristics of the $T$. sordida [14,17,50]; and 5) spraying cycle discontinuity, for administrative and budget related reasons [49,51-53]. All of these factors pointed out, isolated or associated, expose the triatomine to sub-lethal doses selecting the least susceptible.

Beyond this, the study area of this work presents overlapping with the dengue and leishmaniasis endemics. Both programs execute simultaneously and without coordination among themselves, their vector chemical control activities, each one meeting their specific characteristics. Together with this fact, the utilization of agricultural and domestic insecticides signifies an exacerbated chemical pressure over the triatomine populations of the region, which can contribute to the indiscriminate and unwanted increase of insecticide resistance [17].

\section{Conclusions}

Considering the different toxicological profiles observed in the populations of T.sordida studied in this work, associated with the large ecological valence of this triatomine species, the necessity of more in-depth studies, investigating the real impact of the $R R_{50}$ on the vector control activities in the field, is reinforced. The evaluation of this information, considering the environmental conditions into which the triatomine populations find themselves inserted and the genetic variability of the same will permit the establishment of rational and feasible strategies for the vector control of this specie.
Competing interests

The authors declare that they have no competing interests.

\section{Authors' contributions}

All authors have contributed substantially to this study. Conceived and designed the experiments: GCDP, LD. Contributed material biologic: BVM, JGR. Performed the experiments: GCDP Analyzed the data: GCDP,LD Wrote the manuscript: GCDP, LD. All authors read and approved the final manuscript.

\section{Acknowledgements}

This study was supported by the Conselho Nacional de Desenvolvimento Científico e Tecnológico (CNPq), Centro de Pesquisa Rene Rachou (CPqRR), Fundação Oswaldo Cruz (FIOCRUZ), Secretaria de Vigilância em Saúde (SVS), Ministério da Saúde (MS) - Brazil - and World Health Organization (WHO). We thank to Secretaria de Saúde do Estado de Minas Gerais (SES/MG) for the collection of Triatominae, to Bayer S.A. Brazil for providing the insecticide used and to Dr. João Victor Leite Dias for map and suggestions.

\section{Author details}

${ }^{1}$ Laboratório de Triatomíneos e Epidemiologia da Doença de Chagas/CPqRR/ FIOCRUZ, Centro de Pesquisas René Rachou, Fundação Oswaldo Cruz, Av. Augusto de Lima 1715, Barro Preto, 29190-002 Belo Horizonte, MG, Brazil. ¿2aboratório de Entomologia, Universidade Federal de Brasília, Brasília, DF, Brazil. ${ }^{3}$ Gerência Regional de Saúde de Montes Claros, Montes Claros, MG, Brazil. ${ }^{4}$ Secretaria de Saúde do Estado de Minas Gerais, Belo Horizonte, MG, Brazil.

Received: 10 February 2015 Accepted: 23 April 2015

Published online: 08 May 2015

\section{References}

1. $\mathrm{WHO}$, World Health Organization. Chagas disease (American trypanosomiasis) [online]Marc2015 [accessed 11.March.2015]. In: http://www.who.int/ mediacentre/factsheets/fs340/en/

2. Schofield CJ, Jannin J, Salvatella R. The future of Chagas disease control. Trends Parasitol. 2006;22:583-8.

3. Dias JCP. Doença de Chagas: sucessos e desafios. Cad Saude Publica. 2006:22:2020-1.

4. Oscherov EB, Damborsky MP, Bar ME, Gorla DE. Competition between vectors of Chagas disease, Triatoma infestans and T. sordida: effects on fecundity and mortality. Med Vet Entomol. 2004;18:323-8.

5. Silveira AC. Situação do controle da transmissão vetorial da doença de Chagas nas Américas. Cad Saúde Públ. 2000;16(2):43-59.

6. Forattini OP. Biogeografia, origem e distribuição da domiciliação de triatomíneos no Brasil. Rev Saude Publ. 1980;14:265-99.

7. Forattini OW, Ferreira OA, Rocha e Silva EO, Rabello EX. Aspectos ecológicos da Tripanossomíase americana. XIV. Persistência e potencial de domiciliação de populações triatomínicas silvestres em reigão de intensa atividade agropecuária. Rev Saúde Publ. 1979;13:123-46.

8. Forattini OP, Ferreira OA, Rocha e Silva EO, Rabello EX, Santos JLF. Aspectos ecológicos da tripanossomíase Americana. II. Distribuição e dispersão local de triatomíneos em ecótopos naturais e artificiais. Rev Saude Publ. 1971;5:163-91.

9. Forattini OP, Rocha e Silva EO, Ferreira AO, Rabello EX, Patolli DGB. Aspectos ecológicos da tripanossomíase Americana. III. Dispersão local de triatomíneos, com especial referência ao Triatoma sordida. Rev Saude Publ. 1971;5:193-205.

10. Schofield CJ, Lehane MJ, McEwan P, Catala SS, Gorla DE. Dispersive flight by Triatoma sordida. Trans R Soc Trop Med Hyg. 1991;85:676-8.

11. Noireau F, Zegarra M, Ordõnez J, Gutierrez T, Dujardin JP. Genetic structure of Triatoma sordida (Hemiptera:Reduviidae) domestic populations from Bolivia: application on control interventions. Mem Inst Oswaldo Cruz. 1999:94(3):347-51.

12. Wisniveky-Colli C, Gurtler RE, Solarz ND, Schweigmann NJ, Pietrokovsky SM, Alberti A, et al. Dispersive fligh and house invasion by Triatoma guasayana and Triatoma sordida in Argentina. Mem Inst Oswaldo Cruz. 1993;88(1):27-32.

13. Coura JR. O falso dilema sobre a luta antivetorial e as perspectivas de controle da Doença de Chagas no Brasil. Cad Saúde Públ. 1993;9(4):514-8. 
14. Diotaiuti L, Azeredo BVM, Busek SCU, Fernandes AJ. Controle do Triatoma sordida no Peridomicílio Rural do Município de Porteirinha, Minas Gerais, Brasil. Rev Pan Salud Pública. 1998;3:21-5.

15. Mendes PC, Lima SC. Influência do clima na ocorrência de triatomíneos no município de Uberlândia-MG. Caderno de Geografia. 2011;33(2):5-20.

16. Obara MT, Otrera VCG, Gonçalves RG, Santos JP, Santalucia M, Rosa JA, et al. Monitoramento da suscetibilidade de populações de Triatoma sordida Stål, 1859 (Hemiptera: Reduviidae) ao inseticida deltametrina, na região Centro-Oeste do Brasil. Rev Soc Bras Med Trop. 2011;44(2):206-12.

17. Pessoa GCA. Perfil da suscetibilidade a deltametrina em populações de Triatoma sordida (Hemiptera: Reduviidae) do Estado de Minas Gerais procedentes de áreas com infestação persistente, Tese de Doutorado, Universidade Federal de Minas Gerais, Belo Horizonte. 2012. 179.

18. Instituto Brasileiro de Geografia e Estatística - IBGE. Censo demográfico. Brasília, 1992.

19. Organización Panamericana de la Salud (PAHO). II Reunion técnica latinoamericana de monitoreo de resistência a insecticidas em triatominos vectores de Chagas, OPS. Panamá: PAHO; 2005.

20. World Health Organization (WHO). Taller sobre la evaluación de efecto insecticida sobre triatominos. Workshop on the insecticide effect evaluation in triatominos. Acta Toxicol Argentina. 1994;2:29-33.

21. Pessoa GCC. Monitoramento da suscetibilidade ao piretróide deltametrina em populações de Triatoma sordida Stål, 1859 (Hemiptera: Reduviidae). [Masters Thesis]. [Belo Horizonte]: Centro de Pesquisas René Rachou, Fundação Oswaldo Cruz; 2008. 95 p.

22. Raymond M, Prato G, Ratsira D. PROBIT analysis of mortality assays displaying quantal response, version 3.3. France: Praxéme Sarl: St. Georges dÓrques; 1993.

23. Robertson JL, Russel RM, Savin NG. Polo: A user's guide to Probit or Logit analysis. Gen Tech Rep PSW-38 1980; 15p.

24. Vassena CV, Picollo MI, Zerba EN. Insecticida resistance in Brazilian Triatoma infestans and Venezuelan Rhodnius prolixus. Med Vet Entomol. 2000;14:51-5.

25. Sonoda IV, Pessoa GCD, Cortez MR, Dias JC, Romanha AJ, Diotaiuti L. Susceptibility of Triatoma infestans to deltamethrin in Rio Grande do Sul. Brazil Mem Inst Oswaldo Cruz. 2009;104(4):668-70.

26. Obara TM. Caracterização da resistência a inseticidas em populações da subfamília Triatominae (Hemiptera:Reduviidae), vetores de Trypanosoma cruzi Chagas, 1909. Tese de Doutorado, Universidade de São Paulo, 2010; 246.

27. Pessoa GCD, Dias LS, Diotaiuti L. Deltamethrin pyrethroid susceptibility characterization of Triatoma sordida Stal, 1859 (Hemiptera:Reduviidae) populations in the Northern Region of Minas Gerais. Rev Soc Med Trop. 2014:47(4):426-9.

28. Pessoa GCD, Pinheiro LC, Ferraz M, Mello BV, Diotaiuti L. Standartization of laboratory bioassays for the study of Triatoma sordida susceptibility to pyrethroid insecticides. Parasites Vectors 2015, http://dx.coi.org/10.1186/s12971-015-0726-4.

29. Toloza AC, Germano M, Cueto GM, Vassena C, Zerba E, Picollo MI. Differencial patterns of insecticide resistance in eggs and first instar of Triatoma infestans (Hemiptera: Reduviidae) from Argentina and Bolivia. J Med Entomol. 2008:45:421-6.

30. Santo-Orihuela PL, Vassena CV, Zerba EN, Picollo MI. Relative contribution of monooxygenase and esterase to pyrethroid resistance in Triatoma infestans (Hemiptera: Reduviidae) from Argentina and Bolivia. J Med Entomol. 2008:45:298-6.

31. Germano MD, Vassena CV, Picollo MI. Autosomal inheritance of deltamethrin resistance in field populations of Triatoma infestans (Heteroptera: Reduviidae) from Argentina. Pest Manag Sci. 2010;66:705-8.

32. Lardeux F, Depickère $S$, Cuchon $S$, Chaves $T$. Insecticide resistance of Triatoma infestans (Hemiptera, Reduviidae) vector of Chagas disease in Bolivia. Trop Med Inter Health. 2010;15:1037-48.

33. Roca-Acevedo G, Mougabure Cueto GA, Germano M, Orihuela PS, Cortez MR, Noireau F, et al. Susceptibility of sylvatic Triatoma infestans from Andeans Valleys of Bolivia a deltamethrin and fipronil. J Med Entomol. 2011:48:829-35.

34. Depickère $S$, Buitrago $R$, Siñani $E$, Baune $M$, Monje $M$, Lopez $R$, et al. Susceptibility and resistance to deltamethrin of wild and domestic populations of Triatoma infestans (Reduviidae: Triatominae) in Bolivia: new discoveries. Mem Inst Oswaldo Cruz. 2012;107(8):1042-7.

35. Germano MD, Santo-Orihuela P, Roca-Acevedo G, Toloza AC, Vassena C, Picollo Ml, et al. Scientific evidence of three different insecticide-resistant profiles in Triatoma infestans (Hemiptera:Reduviidae) populations from Argentina and Bolivia. J Med Entomol. 2012;49:1355-60.
36. Roca-Acevedo G, Piollo MI, Santo-Orihuela. Expression of insecticide resistance in immature life stages of Triatoma infestans (Hemiptera:Reduviidae). J Med Entomol. 2013;50(4):816-8.

37. Gomez MB, Pessoa GCD, Orellana ALG, Cortez MR, Rosa ACL, Noireau F, et al. Susceptibility to deltamethrin of wild and domestic populations of Triatoma infestans of the Gran Chaco and the Inter-Andean Valleys of Bolivia. Parasit Vectors. 2014;7:497.

38. González-Audino P, Vassena C, Barrios S, Zerba EN, Picollo MI. Role of enhanced detoxication in a deltamethrin-resistant population of Triatoma infestans (Hemiptera, Reduviidae) from Argentina. Mem Inst Oswaldo Cruz. 2004;99:335-9.

39. Picollo MI, Vassena C, Orihuela PS, Barrios S, Zaidemberg M, Zerba E. High resistence to pyrethroid insecticides associated with ineffective field treatments in Triatoma infestans (Hemipetra: Reduviidade from Northern Argentina. J Med Entomol. 2005:42:637-42.

40. Sfara V, Zerba EM, Alzogaray RA. Toxicity of pyrethroids and repellency of diethyltoluamide in two deltamethrin-resitant colonies of Triatoma infestans Klug, 1834 (Hemiptera:Reduviidae). Mem Inst Oswaldo Cruz. 2006;101:89-94.

41. Germano MD, Acevedo GR, Mougabure Cueto GA, Toloza AC, Vassena CV, Picollo MI. New findings of insecticide resistance in Triatoma infestans (Heteroptera: Reduviidae) from the Gran Chaco. J Med Entomol. 2010:47(6):1077-81.

42. Fabro J, Sterkel M, Capriotti N, Mougabure-Cueto G, Germano M, Rivera-Pomar $\mathrm{R}$, et al. Identification of a point of mutation associated with pyrethroid resistance in the para-type sodium channel of Triatoma infestans, a vector of Chagas disease. Infect Genetic Evol. 2012;12:487-91.

43. Canvajal G, Mouganbure-Cueto G, Toloza AC. Toxicity of non-pyrethroid insecticides against Triatoma infestans (Hemiptera:Reduviidae). Mem Inst Oswaldo Cruz. 2012;107(5):675-9.

44. Germano MD, Picollo MI, Mouganbure CG. Microgeographical study of insecticide resistance in Triatoma infestans from Argentina. Acta Trop. 2013;128:561-5.

45. Chilcutt CF, Tabashnik BE. Evolution of pesticide resistance and slope of the concentration-mortality line: are they related? J Econ Entomol. 1995;88:11-20.

46. Ministério da Saúde. Portaria $n^{\circ} 1.399,15$ de dezembro de 1999. Regulamenta a NOB SUS 01/96 no que se refere às competências da União, estados, municípios e Distrito Federal, na área de epidemiologia e controle de doenças, define a sistemática de financiamento e dá outras providências. Diário Oficial da União, 16 dez. 1999; Seção 1:4

47. Rojas De Arias A, Lehane MJ, Schofield CJ, Fournet A. Comparative evaluation of pyrethroid insecticide formulations against Triatoma infestans (Klug): residual efficacy on four sunstrates. Mem Inst Oswaldo Cruz. 2003:98:975-80.

48. Rojas De Arias A, Lehane MJ, Schofield CJ, Maldonado M. Pyrethroid insecticide evaluation on different house structure in a Chagas disease endemic área of the Paraguayan Chaco. Mem Inst Oswaldo Cruz. 2004;99(6):6657-62.

49. Gurtler RE, Canale DM, Spillmann C, Striolo R, Salomón OD, Blanco S, et al, Effectiveness of residual spraying of peridomestic ecotopes with deltamethrin and permethrin on Triatoma infestans in rural western Argentina: a district wide randomized trial. Bull World Health Organ. 2004;82:196-205.

50. Diotaiuti $L$, Dias JCP. O peridomicílio no controle vetorial da doença de Chagas, com especial referência ao Triatoma sordida em Minas Gerais. In: Resumos da V Reunião de Pesquisa Aplicada em doença de Chagas, Araxá 1988; p.79.

51. Diotaiuti L, Pinto CT. Suscetibilidade biológica do Triatoma sordida e Triatoma infestans a deltametrina e lambdacyalotrina em condições de campo. Rev Soc Bras Med Trop. 1991;24:151-5.

52. Prata AR. Situação e Perspectivas do Controle das Doenças Infecciosas e Parasitárias. Brasília: Editora Universidade de Brasília; 1981. p. 317-9.

53. Porcasi X, Catala SS, Hellac H, Scavuzzo MC, Gorla DE. Infestation of rural houses by Triatoma infestans (Hemiptera:Reduviidae) in Southern área of Gran Chaco in Argentina. J Med Entomol. 2006;43:1060-7. 